\title{
35. INTERSTITIAL WATER STUDIES ON SMALL CORE SAMPLES, LEG 23 (RED SEA) ${ }^{1}$
}

\author{
Frank T. Manheim,${ }^{2}$ Lee S. Waterman, ${ }^{3}$ Ching Chang Woo, ${ }^{2}$ and Fred L. Sayles ${ }^{3}$
}

\begin{abstract}
Sites 225,277 , and 228 in the central and southern-central Red Sea show classical diffusion gradients, approaching saturation in interstitial $\mathrm{NaCl}$ with depth as halite beds are approached. Site 228 did not actually encounter halite, but interstitial gradients suggest that it was only several tens of meters deeper than the bottom of the hole. $\mathrm{K}$ and $\mathrm{Mg}$ were characteristically depleted with depth until the evaporitic layers were approached. Then these constituents and also $\mathrm{B}$ and $\mathrm{Li}$ increased sharply. At Site 227 , intra-halite pore fluids were strongly enriched in $\mathrm{Mg}(17 \mathrm{~g} / \mathrm{k}$ $\mathrm{Mg}$ ) and $\mathrm{Ca}(6.7 \mathrm{~g} / \mathrm{kg})$, indicating the presence of late stage evaporites, dominated by tachyhydrite, in the salt beds.

The brines associated with evaporite beds resembled the brines in the hot brine metalliferous deeps only in total dissolved solids (about $250 \mathrm{~g} / \mathrm{kg}$ ); chemical composition was notably different. This confirms other evidence that the hot brine deep fluids do not have a local origin but probably rise from deeper layers through fracture channels.

Site 229 showed a relatively small increase in chlorinity $(21.5$ $\mathrm{g} / \mathrm{kg}$ at sea floor to $27 \mathrm{~g} / \mathrm{kg}$ at $210 \mathrm{~m}$ ). However, considering the extremely rapid rate of accumulation of Quaternary and Pleistocene sediments, this gradient is regarded as sufficient to suggest the presence of salt at depth here also. In contrast, an evaporitic episode in the Red Sea during the Wisconsin glacial maximum, as suggested by Friedman (1972), is not supported by the pore fluid data. Some evaporation and enhancement in salinity in the Red Sea may have occurred, but conditions sufficiently extreme to lay down evaporites in the sea as a whole probably did not occur.

The hot brine deep sediments yielded interstitial fluids roughly comparable with previous analyses both of the hot brines themselves and of associated interstitial waters.
\end{abstract}

\section{INTRODUCTION}

The Red Sea drill holes provided unique opportunities for interstitial water studies. The onboard fluid extractions and determinations of total salinity (by refractometer) soon indicated the presence of salt deposits at depth at Site 225, as well as elsewhere in the Red Sea. It was possible to document, in considerable detail, changes in pore fluid composition approaching and also within rock salt beds, owing to the policy of continuous coring. Since rock salt is virtually impermeable to either fluid flow or ionic diffusion via interconnected porosity, an opportunity was also provided to sample water originally contained in, and between, evaporitic rocks at the time of their burial. Thus, Sites 225,227 , and 228 provide a case study for the

\footnotetext{
${ }^{1}$ Authorized by Director, U.S. Geological Survey.

${ }^{2}$ U.S. Geological Survey, Woods Hole, Mass.

${ }^{3}$ Woods Hole Oceanographic Institution, Woods Hole, Mass. Contribution No. 3195 of the Woods Hole Oceanographic Inst.
}

composition of fluids associated with evaporites, leaching and diffusion of dissolved species from buried evaporites, and diagenetic reactions affecting these species on their route upward. The present paper chiefly provides a descriptive survey of the phenomena and does not attempt quantitative assessment of processes occurring in the strata.

Although it was possible to obtain pore fluids from shales even within the highly consolidated evaporitic sequences, the volumes were limited (and continuous coring prevented extensive multiple squeezings). Regrettably, it was not possible to provide fluid for all desirable studies in the deeper portions.

The hot-brine deeps (Site 226, Atlantis II Deep) provided a disappointment, for only shallow and rather disturbed cores were obtained. Hence, it was not possible to obtain pore fluids directly underlying and adjacent to the metalliferous deposits.

In the southern Red Sea Site 229 provided, through its rapid rate of deposition, useful coverage of the Holocene-Pleistocene deposits and conditions in the Red Sea. 


\section{METHODS}

Shipboard methods have been covered in a separate section (Explanatory Notes, Chapter 2), insofar as they do not repeat standard operations on Glomar Challenger (Waterman, 1970). Pore fluids not used immediately for salinity determination (refractometer), field alkalinity measurements, $\mathrm{pH}$, specific gravity, and electrical resistivity were packaged as usual in heat-sealed polyethylene and polypropylene tubes and glass ampules.

Shore laboratory determinations followed previous procedures (Manheim and Sayles, in press) except that most chlorinity determinations (including other halides, bromide, and iodide)were performed with a commercial colorometric titrator, employing about $0.2 \mathrm{~g}$ sample. Cations were analyzed as before by atomic absorption, using seawater (Copenhagen standard) as standards. In view of deviations of the brines from seawater composition, one cannot exclude some systematic errors owing to dissimilarities between samples and standards. The natural deviations of ionic ratios appear to be far larger than probable systematic influences, however. As usual, sodium values by atomic absorption are generally poorer than those obtained by difference between anion species (determined with relatively high precision) and cations (precision 1\%-4\% with occasional lapses of poorer levels). The "noise" shown in the difference values must be attributed briefly to analytical, rather than real, variations. It is clear, however, that some major shifts in sodium behavior, such as sharply declining $\mathrm{NaCl}$ ratios toward the base of Site 227, are due to real effects.

$\mathrm{B}, \mathrm{Ba}, \mathrm{Li}$, and $\mathrm{Sr}$ were determined by direct reading emission spectrometer using high voltage spark excitation and "vacuum cup" electrodes. Beryllium and cadmium served as internal standards.

Special squeezings using a heated squeezer (Manheim, this volume) were performed to assess the influence of rather high presumed temperatures at depth. In the Red Sea, the temperature relationships were reversed from the normal oceanic situation where samples are warmed on being raised to the sea surface and shipboard laboratories. Homogeneity problems, sample manipulations, and analytical scatter may have obscured some of the effects, but shifts in expected directions for $\mathrm{K}$ and $\mathrm{Mg}$ appear to be present, as noted for samples from Sites 225 and 228 below (Table 1). Temperature effects may be inherent in trace metal determinations (Presley et al, this volume), but insufficient sample was available to provide analytical materials.

One might also point out that contamination becomes a more serious problem in very consolidated sediments than unconsolidated ones. The contaminant (drilling fluid) may be relatively minor, but it is often more readily or preferentially extracted during squeezing. A few erratic and probably spurious decreases in chloride and other constituents were clearly noted, and these samples were excluded from the tables. Others remain and are noted with parentheses in Figures 3 and 4.

\section{RESULTS}

\section{Site 225, Near the Atlantis II Hot Brine Deep}

As may be noted in Figure 1 and Table 2, chloride increases gradually and relatively smoothly with depth to about 125 meters. Thereafter, chloride increases sharply down to the halite boundary. $\mathrm{K}$ and $\mathrm{Mg}$ show gradual depletion with depth until they encounter the evaporitic strata, after which they increase to more than 1.2 and 2.3 $\mathrm{g} / \mathrm{kg}$, respectively. Calcium increases to $1.6 \mathrm{~g} / \mathrm{kg}$ before declining sharply in the evaporite zone. It is evident that $\mathrm{K}$ and $\mathrm{Mg}$ are being supplied from leaching of evaporites but are evidently depleted by uptake in the sediments a short distance above the Miocene boundary.

A depletion of Sr (Table 3) similar to that of $\mathrm{Ca}$ also takes place within the evaporite zone, but boron and lithium increase sharply within it.

\section{Site 226, Atlantis II Deep}

The brines extracted from the disturbed sediments in this site resemble the previously described "hot brines" within experimental error, both chemically and isotopically.

\section{Site 227, Near the Atlantis II Hot Brine Deep}

Trends similar to those in Site 225 occur down to the evaporite zone, where there are exceptionally sharp increases in $\mathrm{Mg}$ concentrations and strong enrichment in $\mathrm{Ca}$, to 17 and $6.6 \mathrm{~g} / \mathrm{k}$, respectively. At the same time, strong B, $\mathrm{Li}$, and $\mathrm{Sr}$ enrichments are noted. It is clear that these constituents must be supplied by soluble phases within the evaporites, presumably in the form of late stage evaporites.

TABLE 1

Effect of Temperature on Sample Composition

\begin{tabular}{|c|c|c|c|c|c|c|c|}
\hline Sample Identification & $\begin{array}{l}\text { Subbottom } \\
\text { Depth } \\
\text { (m) }\end{array}$ & Description & $\mathrm{Na}$ & K & $\mathrm{Ca}$ & $\mathrm{Mg}$ & $\mathrm{Cl}$ \\
\hline Sta $22528-1(\mathrm{RT})\left(24^{\circ} \mathrm{C}\right)$ & 212 & $\begin{array}{l}\text { Shale with halite- } \\
\text { anhydrite }\end{array}$ & 95.8 & 1.29 & 0.69 & 2.21 & (153.3) \\
\hline Sta $22528-1(\mathrm{H})\left(50^{\circ} \mathrm{C}\right)$ & 212 & As above & 94.5 & 1.52 & 0.68 & 2.16 & 153.3 \\
\hline Sta $22839-1\left(55^{\circ} \mathrm{C}\right)$ & 324 & $\begin{array}{l}\text { Black-gray shale } \\
\text { with brecciated } \\
\text { anhydrite }\end{array}$ & 68.4 & 0.66 & 1.14 & 1.32 & (110.0) \\
\hline Sta $22839-1\left(24^{\circ} \mathrm{C}\right)$ & 324 & As above & 68.5 & 0.64 & 1.25 & 1.65 & 110.0 \\
\hline
\end{tabular}

Note: This table shows the difference in composition of samples extracted at laboratory temperature $\left(24^{\circ} \mathrm{C}\right)$ from heated $\left(50^{\circ}\right)$ samples. Values are normalized to constant chlorinity. Samples are from adjacent core materials and may be subjected to variable (slight) amounts of evaporation and contamination. Data from Table 2. 


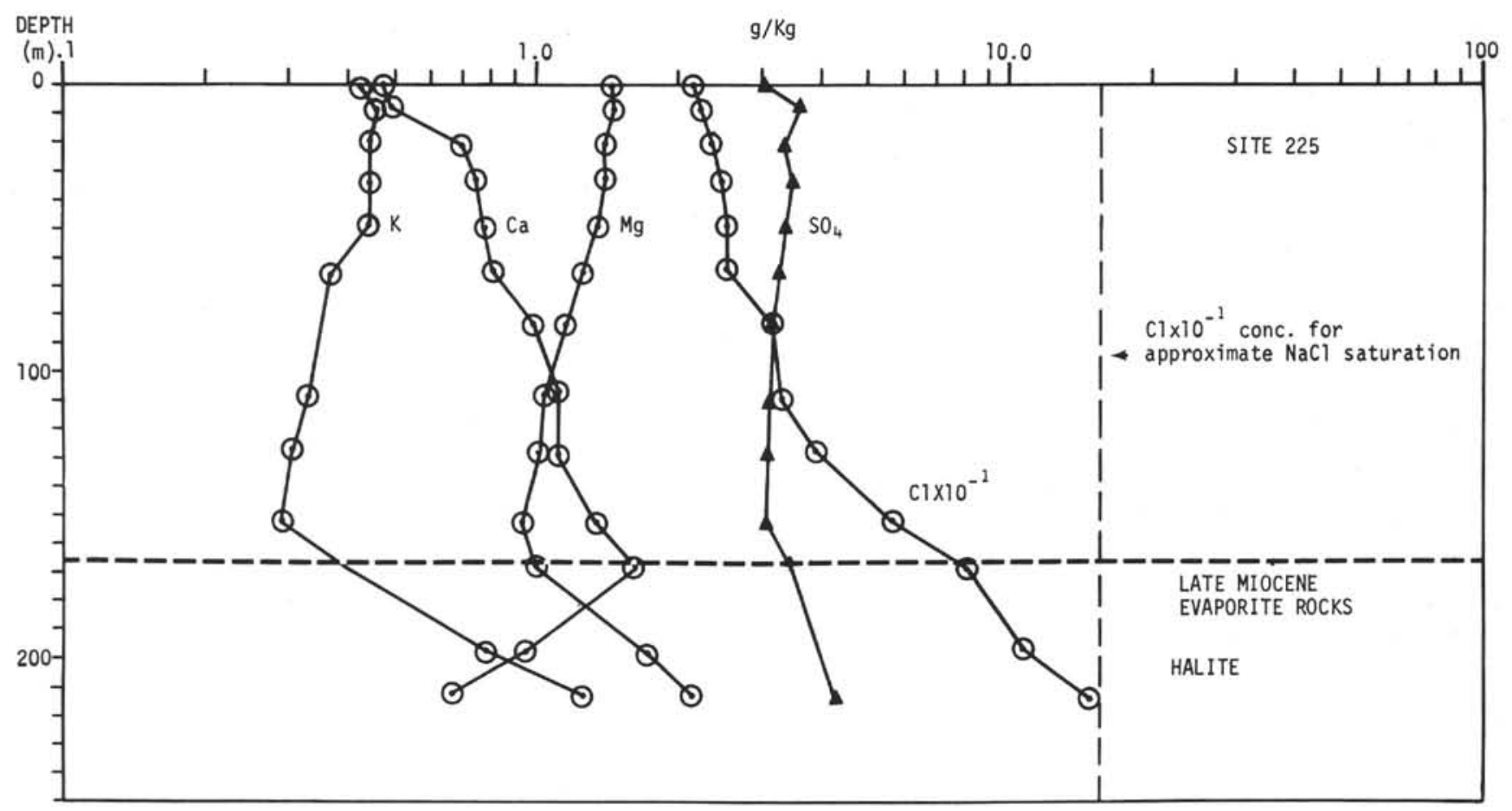

Figure 1. Distribution of major interstitial water components with depth in Site 225 .

Although polyhalites were suggested to be present in this section by Stoffers and Kühn (this volume), it is difficult to account for the observed elemental increments by dissolution of polyhalite. Insufficient $\mathrm{K}$ and sulfate are present for such a reaction (Table 2 and Figure 2). More suitable from the chemical point of view would be minerals of the bischofite $\left(\mathrm{MgCl}_{2} \cdot 6 \mathrm{H}_{2} \mathrm{O}\right)$-tachyhydrite $\left(\mathrm{CaMg}_{2}\right.$ $\mathrm{Cl}_{6} \cdot 12 \mathrm{H}_{2} \mathrm{O}$ ) type.

\section{Site 228, West Side of Red Sea Axial Valley}

Although halite was not penetrated in this site, the increasing interstitial chloride concentrations clearly indicate presence of such beds some tens of meters below penetrated depths (probably less than $100 \mathrm{~m}$ ). This may be inferred not only from chlorinities, but also from magnesium and potassium upswings (Figure 3). A point of interest is the fact that although the evaporitic strata are intensely brecciated and deformed, overlying strata show relatively little deformation and interstitial gradients are smooth and not interrupted as they would be had faulting or other disruption affected them. At Site $228, p H$ values are somewhat higher than at other deep sites, and alkalinities may also be somewhat higher; this is associated with relatively depressed calcium values.

\section{Site 229, Southern Red Sea Near Zebayir Island}

This site differed from the preceding by losing most of its interstitial sulfate within the first 30 meters of depth. Excess methane with increasing ethane pressures were observed at all depths. Alkalinities, high at first, decreased to low values with depth. One can conclude that methane bacteria were probably a dominant source of the methane gas; these bacteria require absence of significant $\mathrm{SO}_{4}$ or other oxygen sources and relatively abundant organic matter.
Diagenetic reactions depleting $\mathrm{K}$ and $\mathrm{Mg}$ and releasing $\mathrm{Ca}$ were marked at this site, similar to previous DSDP sites characterized by rapidly accumulated terrigenous sediments having abundant organic matter. The strontium increases to $142 \mathrm{mg} / \mathrm{kg}$ also suggest that a significant amount of recrystallization of biogenic calcite or other carbonate species to a lower strontium form has taken place (Manheim et al., 1971).

\section{Site 230, Southern Red Sea}

A single core, taken before the drilling vessel was forced to leave the site, nevertheless provided strong evidence that evaporites were present at relatively shallow depth. Chloride increased from a presumed $21.5 \mathrm{~g} / \mathrm{kg}$ in bottom waters to $33.0 \mathrm{~g} / \mathrm{kg}$ at a depth estimated at 9 meters. This conclusion is strengthened by the fact that increases in $\mathrm{Mg}$ and $\mathrm{K}$ were also registered. As one may observe in Figures $1,2,3$, and $5, \mathrm{Mg}$ and $\mathrm{K}$ typically become enriched only within 100 meters or less from evaporite bodies owing to their tendency to be taken up diagenetically in silicate and carbonate minerals.

\section{DISCUSSION}

\section{Origin of Brine at Site 227: Dissolution of Late State Evaporite Minerals (Tachyhydrite)}

The composition of magnesium and calcium rich brines at the bottom of the section at Site 227 presents a problem and an apparent contradiction to the petrographic observations of Stoffers and Kühn (this volume). These authors report needles of polyhalite toward the base of the section at this site and elsewhere. The problem is that the Ca-rich solutions and absence of significant dissolved $\mathrm{SO}_{4}$ or $\mathrm{K}$ appear to be inherently antithetical to either polyhalite $\left(\mathrm{K}_{2} \mathrm{MgCa}_{2}\left(\mathrm{SO}_{4}\right)_{4} \cdot 6 \mathrm{H}_{2} \mathrm{O}\right)$ or appreciable carnal- 
lite $\left(\mathrm{KMgCl}_{3} \cdot 6 \mathrm{H}_{2} \mathrm{O}\right)$. In the case of the former, the calcium concentrations should be brought down to lower levels by anhydrite precipitation with sulfate from polyhalite, whereas there is insufficient $\mathrm{K}$ to account for more than a small proportion of K-rich species. The proportions of soluble salts that have served as parent materials for the brine at 350 meters at Site 227 may be analyzed as follows:

\begin{tabular}{|c|c|c|c|c|c|c|c|c|}
\hline $\begin{array}{l}\text { Chemical } \\
\text { Sequence }\end{array}$ & $\mathrm{Na}$ & K & $\mathrm{Ca}$ & $\mathrm{Mg}$ & $\mathrm{Cl}$ & $\mathrm{SO}^{4}$ & $\begin{array}{l}\text { Total } \\
\text { Solids } \\
(\mathrm{g} / \mathrm{kg})\end{array}$ & $\begin{array}{l}\text { Total } \\
(\mathrm{mol} / \\
\mathrm{kg})\end{array}$ \\
\hline $\begin{array}{l}\text { 1. Starting } \\
\text { brine (in } \\
\mathrm{mol} / \mathrm{kg} \text { ): }\end{array}$ & 2.95 & .023 & .168 & .690 & 4.67 & .0126 & 257.6 & 8.49 \\
\hline $\begin{array}{l}\text { 2. Remov- } \\
\text { ing K as } \\
\text { carnallite } \\
\text { (There is } \\
\text { insuffi- } \\
\text { cient } \\
\text { sulfate } \\
\text { to ac- } \\
\text { commo- } \\
\text { date all } \\
\mathrm{K} \text { as } \\
\text { poly- } \\
\text { halite) } \\
\text { leaves: }\end{array}$ & 2.95 & - & .168 & .667 & 4.60 & .0126 & 252.0 & 8.355 \\
\hline $\begin{array}{l}\text { 3. Remov- } \\
\text { ing } \mathrm{SO}_{4} \\
\text { as an- } \\
\text { hydrite, } \\
\text { leaves: }\end{array}$ & 2.95 & - & .155 & .667 & 4.60 & - & 252.0 & 8.355 \\
\hline $\begin{array}{l}\text { 4. Remov- } \\
\text { ing Na, } \\
\text { as halite, } \\
\text { leaves: }\end{array}$ & - & - & .155 & .667 & 1.65 & - & 81.5 & 2.455 \\
\hline
\end{tabular}

Rounding the remainder (above) and placing in mineral form yields $\mathrm{Ca}_{0.6} \mathrm{Mg}_{2.4} \mathrm{Cl}_{6} .12 \mathrm{H}_{2} \mathrm{O}$, a relative of tachyhydrite $\left(\mathrm{CaMg}_{2} \mathrm{Cl}_{6} .12 \mathrm{H}_{2} \mathrm{O}\right)$ that is not stable at low temperatures, but would be stable at the probable temperatures occurring at the bottom of Site 227 (Braitsch, 1971). have:

Expressing the above mineral phases in percentages we

\begin{tabular}{lcc}
\hline \multicolumn{1}{c}{ Mineral Phase } & $\begin{array}{c}\text { Weight } \\
\text { Percent } \\
\text { of Brine } \\
\text { Salt }\end{array}$ & $\begin{array}{c}\text { Mol } \\
\text { Percent } \\
\text { of Brine } \\
\text { Salt }\end{array}$ \\
\hline Halite $\mathrm{NaCl}$ & 66.3 & 69.4 \\
Tachhydrite $\mathrm{Ca}_{0.6} \mathrm{Mg}_{2.4} \mathrm{Cl}_{6} \cdot 12 \mathrm{H}_{2} \mathrm{O}$ & 31.6 & 29.0 \\
Carnallite $\mathrm{KMgCl}_{3} \cdot 6 \mathrm{H}_{2} \mathrm{O}$ & 1.5 & 1.3 \\
Anhydrite $\mathrm{CaSO}_{4}$ & .5 & .3 \\
\hline
\end{tabular}

As pointed out by Braitsch (1971), based on previous work by D'ans and by Assarson, systems of tachyhydrite, carnallite, and halite are reasonable, particularly at higher temperatures. They may be present far more often than is commonly realized because the assemblage is unstable at lower temperatures and extremely hygroscopic, and thus tends to disappear when cores are brought to the surface.

\section{Wisconsin (Glacial Maximum) Evaporitic Sequence in the Red Sea}

Friedman (1972) has pointed out that during the Wisconsin glacial maximum the presumed sill depth of the Red Sea at Bab el Mandeb should have caused complete closure of the sea with ensuing evaporite deposition. However, no cores examined by him were found to contain evaporites of any kind. He explained this paradox by postulating consumption of the presumed gypsum by sulfate-reducing bacteria to form sulfides.

Although present deuterium data (Friedman, this volume) show a modest possible increase in interstitial $\mathrm{D} / \mathrm{H}$ ratio on the upper part of Site 229 , no significant instestitial anomaly, either in interstitial chloride nor calcium concentration, was found in the upper 10 meters of the sediments as it should have been to confirm the presumed evaporitic episode. Quantitative calculations to establish the relationships have not yet been made, but a qualitative comparison with the Black and Baltic seas, where anomalous (low) salinities were also created during the glacial maximum, indicates that substantial anomalies should remain after some diffusive smoothing in the post-maximum period. Detailed studies of interstitial salinity on numerous piston cores in the Red Sea (during Chain Cruise 100 in 1971) likewise showed no indication of intervening maxima in salinity (Milliman, personal communication, based upon unpublished data).

\section{Origin of the Evaporites: Evidence from Interstitial Fluids}

A notable feature of the brines is their irregular composition, varying from site to site. Clearly, the brine composition reflects the composition of the more soluble components of underlying evaporites. The isotopic data reported elsewhere in this volume (Lawrence, this volume; Friedman, this volume) show a substantial fresh or meteoric component in the deepest brines and, especially, in brines trapped between salt beds. This variability and fresh water influence is consistent with the concept that the evaporites were laid down in shallow-marine evaporating pans that formed highly variable deposits, depending on local topography, runoff, temperature, and other conditions. Such conditions are also reflected in the petrographic relationships (Stoffers and Kühn, this volume). Deepwater evaporites for the strata penetrated in this study are not favored for they should maintain much heavier isotopic relationships as well as much more consistent (geographic) mineral and brine relationships. Of course, we cannot tell the nature of the environment of the early or median evaporites in the presumably thick deposits from evidence near the top of the section.

One outgrowth of the current study might be the conclusion that highly metastable (at surface conditions) and soluble evaporitic minerals may perhaps be better studied by interstitial water analyses on intervening shales than in the cores themselves unless stringent precautions are taken to prevent dissolution or transformation of the 


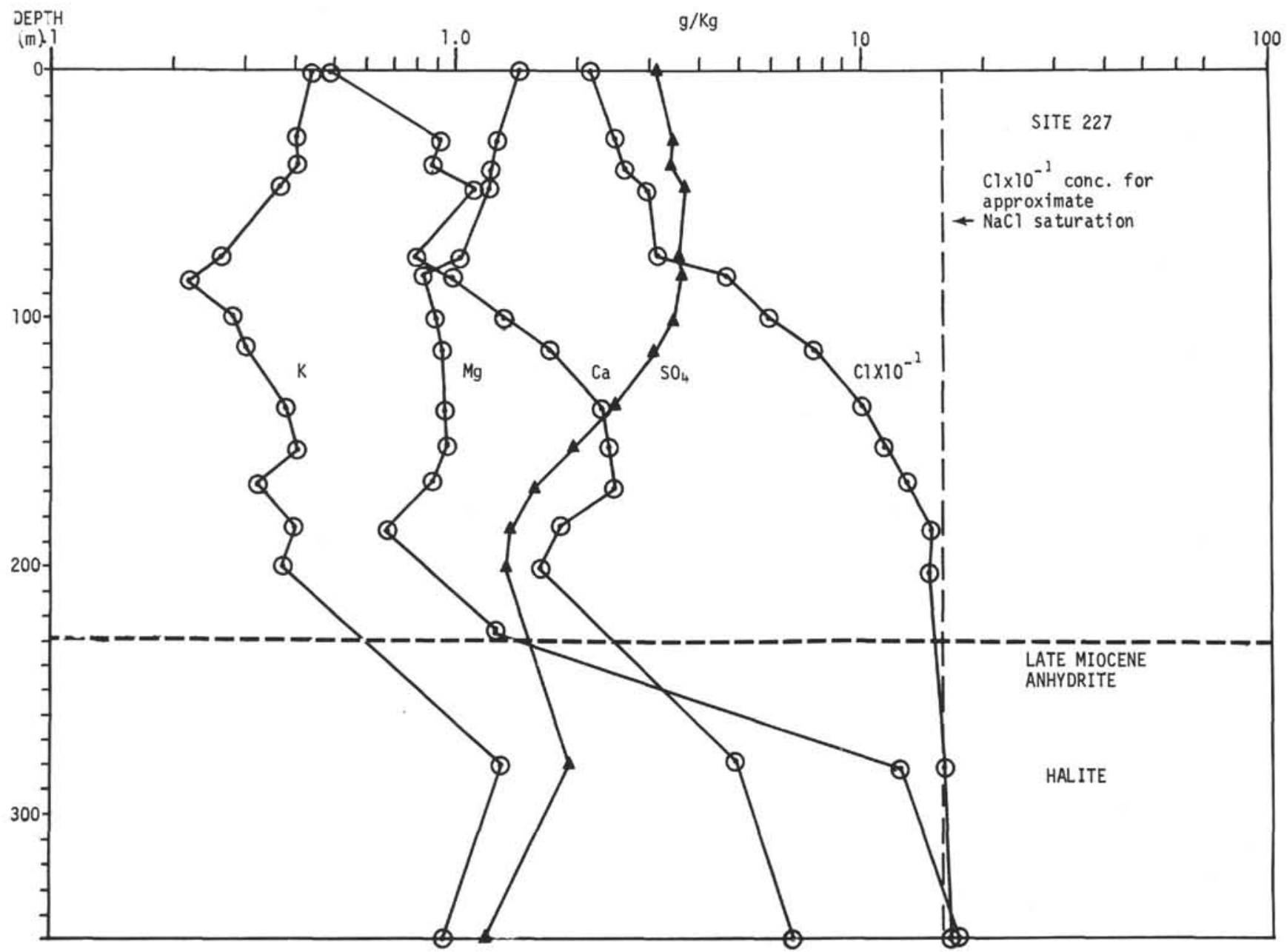

Figure 2. Distribution of major interstitial components with depth in Site 227.

minerals prior to laboratory examination. Diffusion through the shales is a slow process, and extraction of interior uncontaminated pieces can be performed with relatively small change in the brine composition owing to pressure and temperature changes. The temperature changes can also be compensated for in large part. Whereas base exchange (temperature effect) is rapid, mineral precipitation or dissolution within shale beds is generally slow enough so that even metastable solutions can be recovered if extraction is performed immediately.

\section{Relation of the Deep Brines to Fluids from the Atlantis II Deep}

The Atlantis II Deep brines are not only substantially different from the three interstitial brines associated with evaporite sites here, but they have maintained substantial constancy in time and place in interstitial waters (see studies in Degens and Ross, 1969). In this respect, the brines appear to come from a large, permeable and communicating reservoir rather than being locally derived, as is presumed for interstitial waters analyzed from Sites 225,227 , and 228 . Likewise, the substantial heat suggests migration from deeper horizons. Findings of the diffusimeter studies, reported elsewhere in the volume, render it highly unlikely for any of the rocks studied here to yield any sustained flow such as characterizes input into the Atlantis II Deep (Brewer et al., 1971). Thus, the newly analyzed interstitial waters show that, whereas concentrated brines are to be expected at depth throughout the entire evaporite basin of the Red Sea, the brines at the evaporite-normal sediment interface will be variable and are quite different than the hot brines in the metalliferous deeps.

\section{REFERENCES}

Braitsch, O., 1971. Salt deposits, their origin and composition: New York, Heidelberg, (Springer- Verlag), 297 p.

Brewer, P. G., Wilson, T. R. S., Murray, J. W., Munn, R. G., and Densmore, C. D., 1971. Recent hydrographic observations on the Red Sea brines. A marked temperature increase: Nature, 231, p. 37.

Degens, E. T. and Ross, D. A., 1969. Hot brines and recent heavy metal deposits in the Red Sea: New York, Heidelberg, (Springer-Verlag), 600p.

Friedman, G. M., 1972. Significance of Red Sea in problem of evaporites and basinal limestones: Am. Assoc. Petrol. Geol., Bull. 56, p. 1072.

Manheim, F. T., Sayles, F. L., and Waterman, L. S., 1971. Interstitial water studies on small core samples, Deep Sea Drilling Project, Leg 8. In Tracey, J. I., Jr., Sutton, 
G. H., et al., Initial Reports of the Deep Sea Drilling Project, Volume VIII: Washington (U.S. Government Printing Office), p. 857.

Manheim, F. T. and Sayles, F. L. in press. Composition and origin of interstitial waters of marine sediments, based on deep sea drill cores. In Goldberg, E. D. (Ed.), The Sea: New York (Interscience), v. 5 (Sillen Memorial).

Waterman, L. S., 1970. Interstitial water program, shipboard manual: Deep Sea Drilling Project, Scripps Inst. of Oceanography, La Jolla. 141 p.

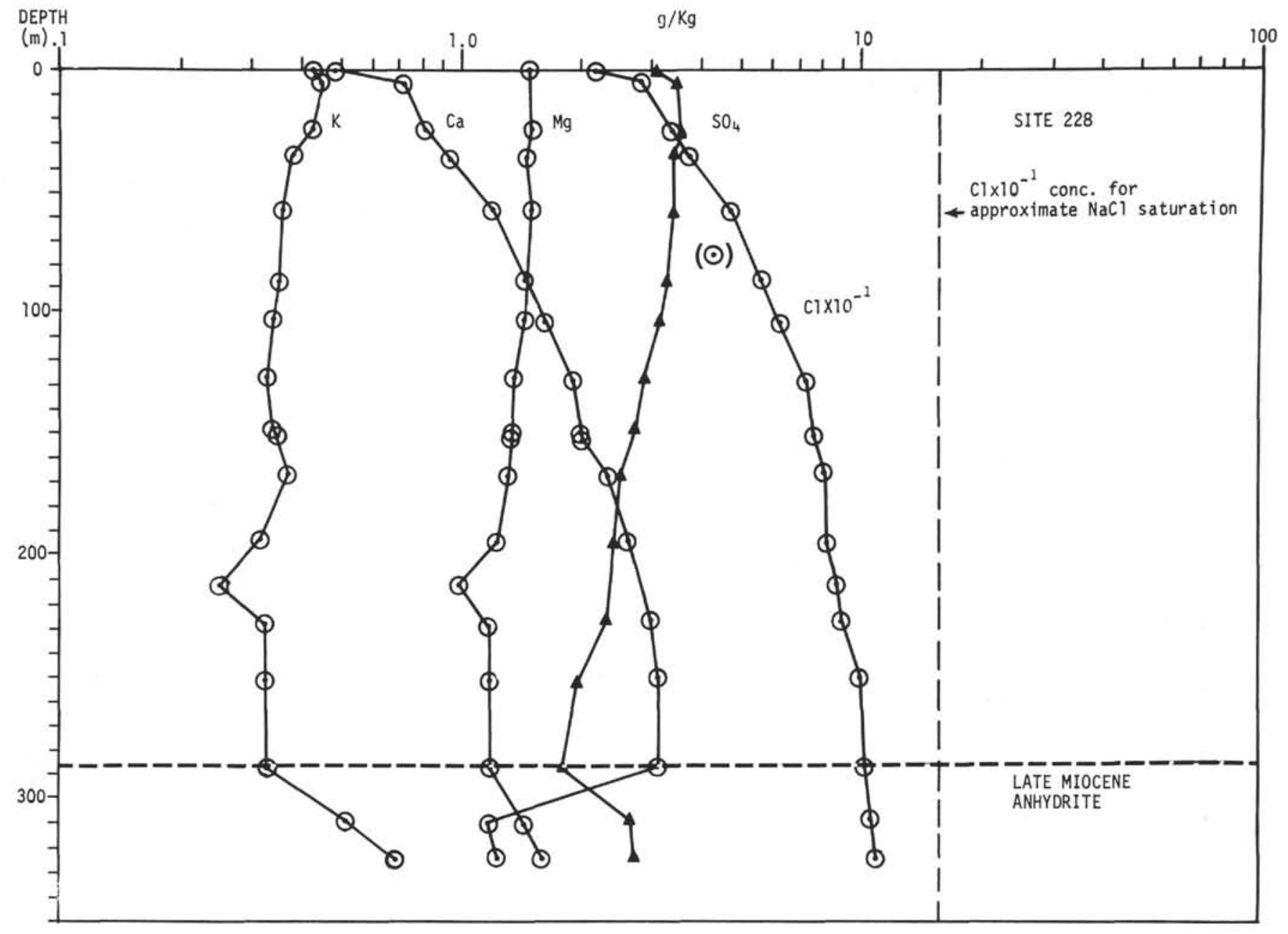

Figure 3. Distribution of major interstitial components with depth in Site 228. 


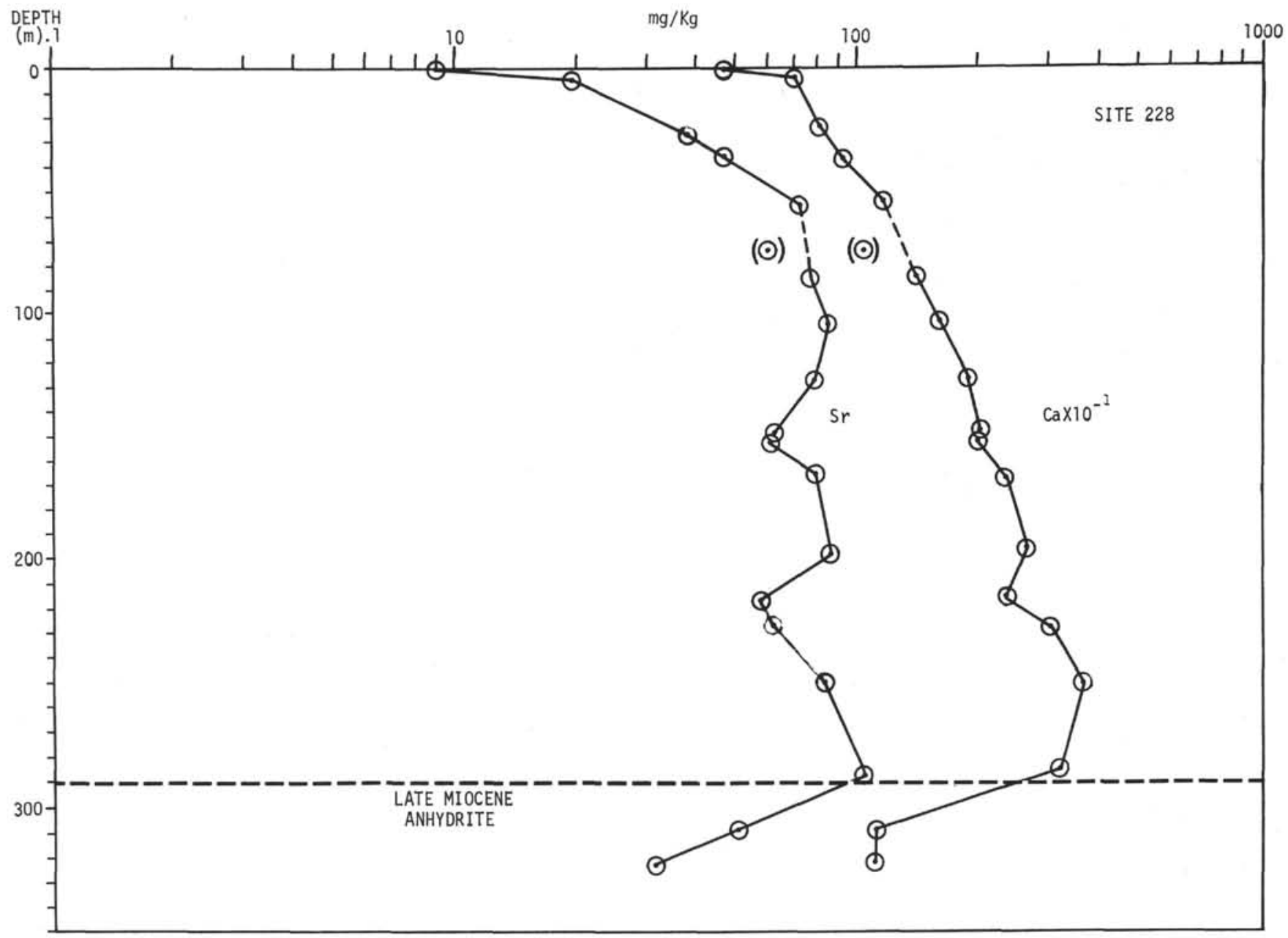

Figure 4. Distribution of interstitial strontium and calcium with depth in Site 228.

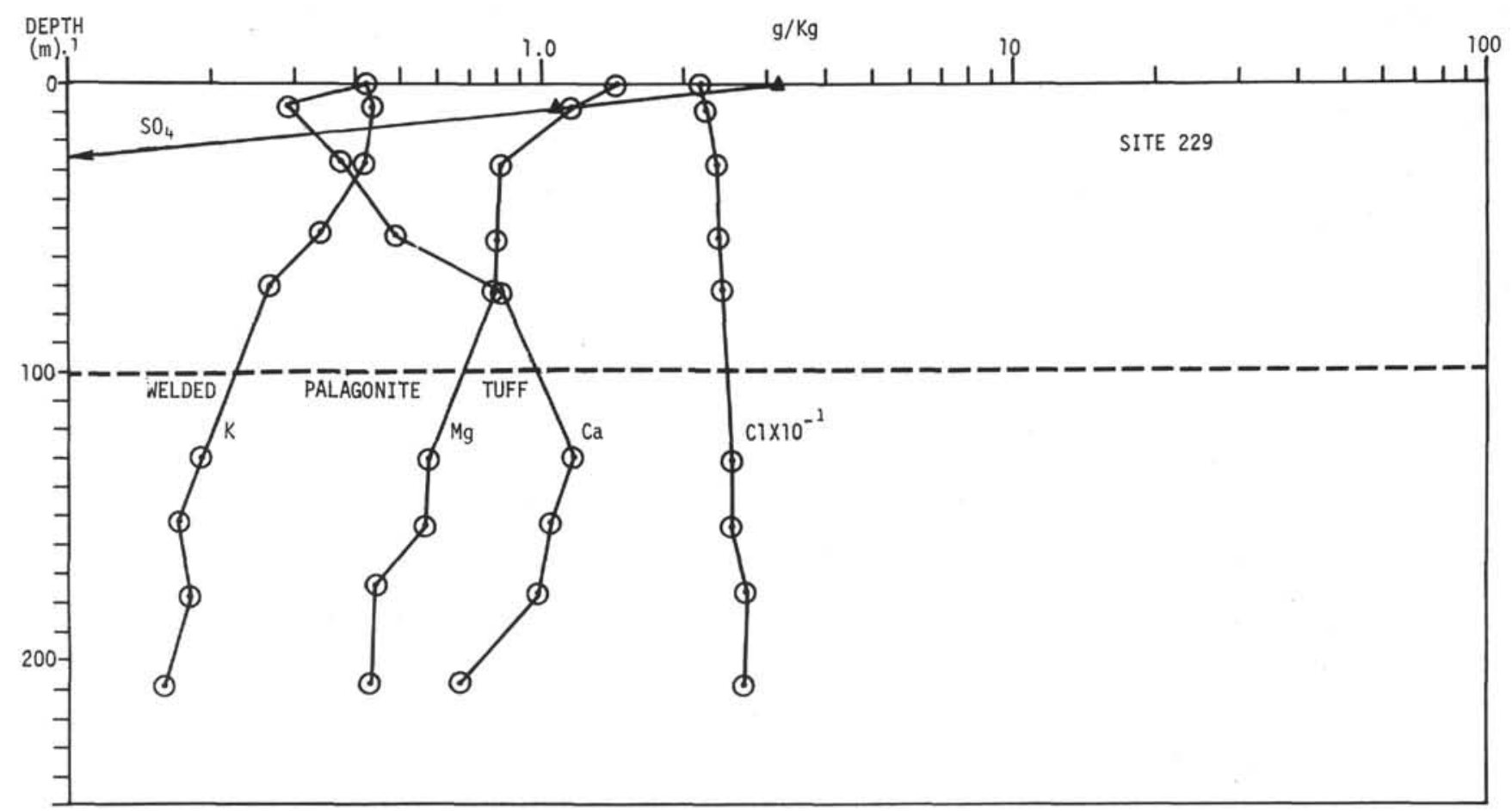

Figure 5. Distribution of major interstitial components with depth in Site 229. 
TABLE 2

Major Constituents of Interstitial Waters, Leg 23 (Red Sea)

\begin{tabular}{|c|c|c|c|c|c|c|c|c|c|c|c|c|c|c|c|c|c|c|}
\hline $\begin{array}{c}\text { Sample } \\
\text { Core, Section }\end{array}$ & $\begin{array}{l}\text { ubbottom } \\
\text { Depth } \\
\text { (m) }\end{array}$ & Age & Description & $\mathrm{Na}^{1}$ & $\mathrm{Na}^{2}$ & $\mathrm{~K}$ & $\mathrm{Ca}$ & $\mathrm{Mg}$ & $\begin{array}{c}\text { Total } \\
\text { Cations }\end{array}$ & $\mathrm{Cl}$ & $\mathrm{SO}_{4}$ & Alk & $\mathrm{HCO}_{3}$ & $\begin{array}{c}\text { Total } \\
\text { Anions }\end{array}$ & Sum & $\begin{array}{l}\text { Salin- } \\
\text { ity }\end{array}$ & $\mathrm{H}_{2} \mathrm{O}$ & $p \mathrm{H}$ \\
\hline \multicolumn{19}{|c|}{ Site $225\left(21^{\circ} 18.6^{\prime} \mathrm{N}, 38^{\circ} 15\right.$.'E; water depth $1228 \mathrm{~m} ; 16 \mathrm{~km} \mathrm{E}$ of Atlantic II Deep) } \\
\hline Surface ocean wate & & & & 12.0 & 12.1 & 0.43 & 0.47 & 1.42 & 676 & 21.5 & 3.07 & $(2.4)$ & $(0.14)$ & 612 & 39.1 & 39.9 & & 3.5 \\
\hline $1-5$ & 8 & $\begin{array}{l}\text { Late } \\
\text { Pleistocene }\end{array}$ & Yellowish-brown detrital clayey silt & 12.6 & 12.5 & 0.46 & 0.49 & 1.47 & 708 & 22.5 & 3.62 & 1.9 & 0.12 & 711 & 41.2 & 41.3 & 35 & 7.7 \\
\hline 3-4 & 21 & $\begin{array}{l}\text { Late } \\
\text { Pleistocene }\end{array}$ & $\begin{array}{l}\text { Greenish-gray detrital clayey silt } \\
\text { mixed with foram-bearing } \\
\text { carbonate ooze; highly deformed }\end{array}$ & 13.2 & 13.2 & 0.45 & 0.70 & 1.40 & 746 & 23.8 & 3.36 & 4.5 & 0.28 & 745 & 43.2 & 43.5 & 26 & 7.6 \\
\hline $5-6$ & 34 & $\begin{array}{l}\text { Late } \\
\text { Pleistocene }\end{array}$ & $\begin{array}{l}\text { Olive-gray detrital silty clay mixed } \\
\text { with nanno-rich carbonate ooze; } \\
\text { soft, intensely disturbed }\end{array}$ & 13.9 & 13.9 & 0.45 & 0.75 & 1.41 & 768 & 24.6 & 3.44 & 2.2 & 0.13 & 768 & 44.7 & 45.4 & 41 & 7.7 \\
\hline $8-3$ & 50 & $\begin{array}{l}\text { Early } \\
\text { Pleistocene }\end{array}$ & $\begin{array}{l}\text { Gray detrital clayey silt with } \\
\text { foram - bearing carbonate ooze; } \\
\text { soupy to soft; intensely disturbed }\end{array}$ & 14.4 & 14.1 & 0.44 & 0.77 & 1.36 & 773 & 25.3 & 3.37 & 1.7 & 0.10 & 786 & 45.8 & 45.4 & 36 & 7.9 \\
\hline $10-2$ & 64 & $\begin{array}{l}\text { Late } \\
\text { Pliocene }\end{array}$ & $\begin{array}{l}\text { Greenish-gray detrital silty clay } \\
\text { with nanno-rich carbonate ooze; } \\
\text { soft; intensely deformed }\end{array}$ & 14.4 & 14.3 & 0.37 & 0.82 & 1.26 & 775 & 25.2 & 3.25 & 2.3 & 0.14 & 781 & 45.5 & 45.1 & 28 & 7.6 \\
\hline $13-6$ & 84 & $\begin{array}{l}\text { Late } \\
\text { Pliocene }\end{array}$ & $\begin{array}{l}\text { Dominantly yellowish-green } \\
\text { dolomite bearing detrital silty } \\
\text { clay mixed with foram-rich } \\
\text { carbonate nanno ooze; } \\
\text { disturbed }\end{array}$ & 18.4 & $(16.6)$ & 0.35 & 1.01 & 1.19 & $(880)$ & 31.5 & 3.14 & 2.0 & 0.12 & 954 & 55.7 & 52.0 & 25 & 7.5 \\
\hline $16-3$ & 108 & $\begin{array}{l}\text { Late } \\
\text { Pliocene }\end{array}$ & $\begin{array}{l}\text { Olive-gray dolomite bearing } \\
\text { detrital clay and nanno ooze; } \\
\text { brecciated by drilling }\end{array}$ & 19.4 & 19.0 & 0.33 & 1.11 & 1.04 & 975 & 32.8 & 3.10 & 1.4 & 0.09 & 993 & 57.8 & 53.1 & 13 & 7.6 \\
\hline $18-4$ & 128 & $\begin{array}{l}\text { Early } \\
\text { Pliocene }\end{array}$ & $\begin{array}{l}\text { Greenish-gray detrital silty clay- } \\
\text { stone interbedded with foram nanno } \\
\text { chalk; moderately disturbed }\end{array}$ & 25.5 & 22.3 & 0.30 & 1.10 & 1.01 & 1117 & 39.0 & 3.08 & 2.0 & 0.12 & 1166 & 68.0 & 65.3 & 25 & 7.2 \\
\hline $21-3$ & 152 & $\begin{array}{l}\text { Early } \\
\text { Pliocene }\end{array}$ & $\begin{array}{l}\text { Gray detrital silty claystone } \\
\text { interbedded with dark olive-gray } \\
\text { nanno chalk }\end{array}$ & 35.0 & 34.3 & 0.29 & 1.37 & 0.93 & 1643 & 57.0 & 3.07 & 2.0 & 0.12 & 1674 & 97.9 & 35.2 & 35 & 7.0 \\
\hline $23-2$ & 168 & $\begin{array}{l}\text { Late } \\
\text { Miocene }\end{array}$ & $\begin{array}{l}\text { Dark gray dolomite-rich with } \\
\text { detrital silty clay interbedded } \\
\text { with black purite-rich claystone }\end{array}$ & 50.5 & 49.9 & 0.40 & 1.62 & 0.99 & 2343 & 81.5 & 3.92 & & & 2370 & 138.4 & 138.7 & 15 & 7.0 \\
\hline $26-1$ & 196 & Miocene & $\begin{array}{l}\text { White anhydrite and black pyrite } \\
\text { dolomitic silty claystone }\end{array}$ & 62.6 & 62.9 & 0.79 & 0.95 & 1.73 & 2945 & 104.0 & & 0.6 & 0.04 & 2934 & 170.1 & 172.0 & & 7.0 \\
\hline 28-1(H) & 212 & Miocene & $\begin{array}{l}\text { White halite-anhydrite and nodular } \\
\text { anhydrite; shale }\end{array}$ & 94.5 & 93.0 & 1.52 & 0.68 & 2.16 & 4335 & 153.3 & $(4.3)$ & 1.0 & 0.06 & 4419 & 250.4 & 242 & & \\
\hline 28-1(RT) & 212 & Miocene & $\begin{array}{l}\text { White halite-anhydrite and nodular } \\
\text { anhydrite; shale }\end{array}$ & 92.7 & 90.7 & 1.25 & 0.67 & 2.14 & 4184 & 148.3 & 4.22 & 1.0 & 0.06 & 4373 & 249.4 & 246 & & \\
\hline
\end{tabular}


TABLE 2 - Continued

\begin{tabular}{|c|c|c|c|c|c|c|c|c|c|c|c|c|c|c|c|c|c|c|}
\hline $\begin{array}{c}\text { Sample } \\
\text { Core, Section }\end{array}$ & $\begin{array}{l}\text { Subbottom } \\
\text { Depth } \\
\text { (m) }\end{array}$ & Age & Description & $\mathrm{Na}^{1}$ & $\mathrm{Na}^{2}$ & $\mathrm{~K}$ & $\mathrm{Ca}$ & $\mathrm{Mg}$ & $\begin{array}{c}\text { Total } \\
\text { Cations }\end{array}$ & $\mathrm{Cl}$ & $\mathrm{SO}_{4}$ & Alk & $\mathrm{HCO}_{3}$ & $\begin{array}{l}\text { Total } \\
\text { Anions }\end{array}$ & Sum & $\begin{array}{l}\text { Salin- } \\
\text { ity }\end{array}$ & $\mathrm{H}_{2} \mathrm{O}$ & $p \mathrm{H}$ \\
\hline \multicolumn{19}{|c|}{ Site $226\left(21^{\circ} 20.5^{\prime} \mathrm{N}, 38^{\circ} 04.9^{\prime} \mathrm{E} \text {; water depth } 2169 \mathrm{~m} \text {; SW part of Atlantis II Deep }\right)^{\mathrm{a}}$} \\
\hline $1-1$ & 1.5 & Holocene & $\begin{array}{l}\text { Reddish-black mud; mixture of } \\
\text { montmorillonite, anhydrite, and } \\
\text { geothite-hematite }\end{array}$ & & 94.8 & 2.07 & 5.90 & 0.65 & & & 0.95 & 0.0 & 0.00 & & & 256 & & 6.1 \\
\hline $1-2$ & 1.6 & Holocene & $\begin{array}{l}\text { Reddish-black mud; mixture of } \\
\text { montmorillonite, anhydrite, and } \\
\text { geothite-hematite }\end{array}$ & 93.8 & 94.1 & 2.07 & 5.91 & 0.70 & 4498 & 158.4 & 0.72 & 0.5 & 0.03 & 4434 & 261.6 & 256 & & 6.0 \\
\hline $1-4(\mathrm{IW})$ & 5 & Holocene & $\begin{array}{l}\text { Reddish-black mud; mixture of } \\
\text { montmorillonite, anhydrite and } \\
\text { geothite-hematite }\end{array}$ & 92.4 & 92.8 & 2.14 & 6.08 & 0.69 & 4452 & 156.6 & 0.87 & 0.1 & 0.01 & 4436 & 238.8 & & & 6.4 \\
\hline $1-4(\mathrm{H})$ & 5 & Holocene & $\begin{array}{l}\text { Reddish-black mud; mixture of } \\
\text { montmorillonite, anhydrite and } \\
\text { geothite-hematite }\end{array}$ & 94.7 & & 1.97 & 5.61 & 0.63 & 4127 & 158.9 & 0.97 & & & 4502 & 262.8 & 244.8 & & 6.4 \\
\hline $1-4(\mathrm{HE})$ & 5 & Holocene & $\begin{array}{l}\text { Reddish-black mud; misture of } \\
\text { montmorillonite, anhydrite and } \\
\text { geothite-hematite }\end{array}$ & 94.8 & 95.1 & 2.14 & 5.90 & 0.67 & 4541 & 159.9 & 0.86 & & & 4527 & 242.9 & 242.9 & & 6.4 \\
\hline \multicolumn{19}{|c|}{ Site $227\left(21^{\circ} 19.9^{\prime} \mathrm{N}, 38^{\circ} 08.0^{\prime} \mathrm{E}\right.$; water depth $1795 \mathrm{~m}$; eastern flank of Atlantis II Deep) } \\
\hline \multicolumn{4}{|c|}{$\begin{array}{l}\text { Surface ocean water } \\
3-1\end{array}$} & 11.8 & 11.8 & 0.43 & 0.46 & 1.42 & 673 & 21.4 & 3.06 & 1.6 & 0.10 & 671 & 28.7 & 39.3 & & 6.3 \\
\hline $3-1$ & 27 & $\begin{array}{l}\text { Late } \\
\text { Pliocene }\end{array}$ & $\begin{array}{l}\text { Grayish dolomite-rich carbonate } \\
\text { nanno ooze. }\end{array}$ & 14.7 & 14.3 & 0.40 & 0.93 & 1.28 & 784 & 24.3 & 3.41 & 1.6 & 0.10 & 758 & 45.2 & 46.4 & 36 & 7.5 \\
\hline $5-2$ & 38 & $\begin{array}{l}\text { Late } \\
\text { Pliocene }\end{array}$ & $\begin{array}{l}\text { Grayish foram-bearing carbonate } \\
\text { nanno chalk }\end{array}$ & 14.7 & 14.6 & 0.40 & 0.88 & 1.28 & 793 & 26.8 & 3.39 & 1.4 & 0.08 & 799 & 46.5 & 46.8 & 29 & 7.2 \\
\hline $6-2$ & 46 & $\begin{array}{l}\text { Late } \\
\text { Pliocene }\end{array}$ & $\begin{array}{l}\text { Gray clay-rich chalk interbedded } \\
\text { with dark green clay and carbonate } \\
\text { rich nanno chalk }\end{array}$ & 17.1 & 17.0 & 0.27 & 1.11 & 1.21 & 905 & 29.4 & 3.69 & 1.5 & 0.09 & 706 & 52.9 & 53.4 & 13 & 7.2 \\
\hline $10-2$ & 72 & $\begin{array}{l}\text { Early } \\
\text { Pliocene }\end{array}$ & $\begin{array}{l}\text { Gray carbonate-rich nanno ooze, } \\
\text { disturbed by drilling }\end{array}$ & 19.0 & 18.9 & 0.26 & 0.78 & 1.02 & 952 & 31.2 & 3.47 & 2.2 & 0.13 & 754 & 55.9 & 55.2 & 21 & 7.1 \\
\hline $12-2$ & 82 & $\begin{array}{l}\text { Early } \\
\text { Pliocene }\end{array}$ & $\begin{array}{l}\text { Greenish-black carbonate and } \\
\text { clay-rich nanno chalk interbedded } \\
\text { with silt-rich carbonate chalk }\end{array}$ & 28.7 & 28.1 & 0.22 & 0.98 & 0.84 & 1354 & 46.1 & 3.57 & 1.5 & 0.09 & 1377 & 80.6 & 78.6 & 19 & (7.0) \\
\hline $14-1$ & 100 & $\begin{array}{l}\text { Early } \\
\text { Pliocene }\end{array}$ & $\begin{array}{l}\text { Gray carbonate-rich nanno chalk; } \\
\text { homogeneous semilithified }\end{array}$ & 36.4 & 35.8 & 0.27 & 1.31 & 0.88 & 1701 & 58.8 & 3.36 & 1.0 & 0.06 & 1727 & 101.1 & 101.7 & 22 & 7.3 \\
\hline $16-1$ & 114 & $\begin{array}{l}\text { Early } \\
\text { Pliocene }\end{array}$ & $\begin{array}{l}\text { Very dark gray nanno-carbonate } \\
\text { chalk }\end{array}$ & 47.2 & 46.1 & 0.30 & 1.70 & 0.92 & 2173 & 76.5 & 3.09 & 1.5 & 0.09 & 2223 & 129.8 & 125.0 & 15 & 7.1 \\
\hline $18-3$ & 136 & $\begin{array}{l}\text { Early } \\
\text { Pliocene }\end{array}$ & Gray carbonate-rich nanno chalk & 61.3 & 61.1 & 0.38 & 2.32 & 0.92 & 2856 & 99.7 & 2.43 & 1.8 & 0.11 & 2865 & 167.2 & 165.9 & 18 & 6.7 \\
\hline $20-3$ & 152 & $\begin{array}{l}\text { Early } \\
\text { Pliocene }\end{array}$ & $\begin{array}{l}\text { Gray silt-rich carbonate- } \\
\text { nanno chalk }\end{array}$ & 69.2 & 69.2 & 0.40 & 2.39 & 0.94 & 3215 & 112.7 & 1.91 & 1.3 & 0.08 & 3219 & 197.6 & 187.0 & 15 & \\
\hline
\end{tabular}


TABLE 2 - Continued

\begin{tabular}{|c|c|c|c|c|c|c|c|c|c|c|c|c|c|c|c|c|c|c|}
\hline $\begin{array}{c}\text { Sample } \\
\text { Core, Section }\end{array}$ & $\begin{array}{l}\text { Subbottom } \\
\text { Depth } \\
\text { (m) }\end{array}$ & Age & Description & $\mathrm{Na}^{1}$ & $\mathrm{Na}^{2}$ & $\mathrm{~K}$ & $\mathrm{Ca}$ & $\mathrm{Mg}$ & $\begin{array}{c}\text { Total } \\
\text { Cations }\end{array}$ & $\mathrm{Cl}$ & $\mathrm{SO}_{4}$ & Alk & $\mathrm{HCO}_{3}$ & $\begin{array}{c}\text { Total } \\
\text { Anions }\end{array}$ & Sum & $\begin{array}{c}\text { Salin- } \\
\text { ity }\end{array}$ & $\mathrm{H}_{2} \mathrm{O}$ & $p \mathrm{H}$ \\
\hline $23-1$ & 167 & $\begin{array}{l}\text { Early } \\
\text { Pliocene }\end{array}$ & $\begin{array}{l}\text { Gray silt-bearing carbonate- } \\
\text { nanno chalk }\end{array}$ & 80.2 & 79.7 & 0.32 & 2.44 & 0.86 & 3669 & 129.7 & 1.55 & 2.0 & & 3690 & 215.1 & 214 & & 6.5 \\
\hline $25-2$ & 186 & $\begin{array}{l}\text { Early } \\
\text { Pliocene }\end{array}$ & $\begin{array}{l}\text { Gray silt-bearing carbonate } \\
\text { nanno chalk }\end{array}$ & 93.6 & 90.6 & 0.50 & 1.81 & 0.67 & 4100 & 149.0 & 1.37 & & & 4230 & 247.0 & 237 & 19 & \\
\hline $27-1$ & 203 & $\begin{array}{l}\text { Early } \\
\text { Pliocene }\end{array}$ & $\begin{array}{l}\text { Gray dolomite-rich claystone } \\
\text { with carbonate and pyrite }\end{array}$ & 91.1 & 90.4 & 0.47 & 1.63 & 0.87 & 4098 & 145.4 & 1.33 & & & 4128 & 240.8 & 240 & 10 & \\
\hline $36-2$ & 282 & $\begin{array}{l}\text { Late } \\
\text { Miocene }\end{array}$ & $\begin{array}{l}\text { Anhydrite and dark shale below } \\
\text { halite }\end{array}$ & 71.0 & 70.7 & 1.29 & 4.88 & 12.6 & 4441 & 157.1 & $1.9^{\mathrm{b}}$ & & & 4469 & 250.7 & 250.5 & 23 & 6.5 \\
\hline $44, \mathrm{CC}$ & 350 & $\begin{array}{l}\text { Late } \\
\text { Miocene }\end{array}$ & $\begin{array}{l}\text { Black shale between halite and } \\
\text { anhydrite beds }\end{array}$ & 67.4 & 67.3 & 0.93 & 6.67 & 16.8 & 4656 & 164.8 & $1.2^{\mathrm{b}}$ & & & 4661 & 257.6 & 256.0 & 14 & 6.2 \\
\hline
\end{tabular}

Site $228\left(19^{\circ} 05.2^{\prime} \mathrm{N}, 38^{\circ} 00.2^{\prime} \mathrm{E}\right.$; water depth $1038 \mathrm{~m}$; W side of Red Sea axial valley)

\begin{tabular}{|c|c|c|c|c|c|c|c|c|c|c|c|c|c|c|c|c|c|c|}
\hline $1, \mathrm{CC}$ & 5 & Holocene & $\begin{array}{l}\text { Gray foram-nanno-carbonate } \\
\text { ooze with detrital clayey silt; } \\
\text { soft, homogeneous }\end{array}$ & 16.2 & 16.4 & 0.45 & 0.71 & 1.50 & 885 & 28.5 & 3.46 & 1.7 & 0.10 & 876 & 50.9 & 52.3 & & \\
\hline $3, \mathrm{CC}$ & 26 & $\begin{array}{l}\text { Late } \\
\text { Pleistocene }\end{array}$ & $\begin{array}{l}\text { Gray foram-nanno-carbonate ooze } \\
\text { with detrital clayey silt; soupy }\end{array}$ & 19.2 & 19.0 & 0.43 & 0.81 & 1.47 & 998 & 33.1 & 3.50 & 1.8 & 0.11 & 1007 & 58.6 & 58.7 & 37 & 7.1 \\
\hline $5-3$ & 36 & $\begin{array}{l}\text { Late } \\
\text { Pleistocene }\end{array}$ & $\begin{array}{l}\text { Greenish-gray foram and } \\
\text { carbonate - rich nanno ooze with } \\
\text { detrital sandy silt }\end{array}$ & 22.1 & 21.7 & 0.38 & 0.94 & 1.45 & 1122 & 37.7 & 3.36 & 2.2 & 0.13 & 1136 & 66.0 & 65.5 & 24 & 7.3 \\
\hline $7-6$ & 58 & $\begin{array}{l}\text { Late } \\
\text { Pleistocene }\end{array}$ & $\begin{array}{l}\text { Gray-olive-green carbonate ooze } \\
\text { and detrital clayey silt }\end{array}$ & 28.3 & 27.9 & 0.36 & 1.20 & 1.50 & 1405 & 47.9 & 3.38 & 2.3 & 0.14 & 1424 & 82.8 & 81.9 & 22 & 7.1 \\
\hline $10-6$ & 76 & $\begin{array}{l}\text { Late } \\
\text { Pleistocene }\end{array}$ & $\begin{array}{l}\text { Greenish-gray and greenish-black } \\
\text { detrital clayey silt and silty } \\
\text { clay }\end{array}$ & 25.4 & 25.0 & 0.35 & 1.04 & 1.45 & 1266 & 42.9 & 3.22 & 2.1 & 0.13 & 1280 & 74.5 & 74.3 & 23 & 7.1 \\
\hline $11-4$ & 87 & $\begin{array}{l}\text { Late } \\
\text { Pleistocene }\end{array}$ & $\begin{array}{l}\text { Olive-gray detrital silty clay- } \\
\text { rich carbonate ooze }\end{array}$ & 34.1 & 33.4 & 0.35 & 1.44 & 1.46 & 1656 & 57.2 & 3.26 & 2.1 & 0.13 & 1684 & 99.9 & 97.4 & 21 & \\
\hline $13, \mathrm{CC}$ & 105 & $\begin{array}{l}\text { Late } \\
\text { Pleistocene }\end{array}$ & $\begin{array}{l}\text { Green detrital sand-silt-clay; } \\
\text { rich in forams }\end{array}$ & 37.8 & 38.3 & 0.34 & 1.61 & 1.44 & 1873 & 63.4 & 3.15 & 1.8 & 0.11 & 1854 & 107.8 & 110.7 & 17 & 6.9 \\
\hline $16-5$ & 129 & $\begin{array}{l}\text { Late } \\
\text { Pleistocene }\end{array}$ & $\begin{array}{l}\text { Gray detrital clayey silt and } \\
\text { carbonate chalk }\end{array}$ & 43.9 & 43.6 & 0.33 & 1.91 & 1.37 & 2112 & 73.2 & 2.91 & 1.4 & 0.08 & 2126 & 123.8 & 122.8 & & 6.9 \\
\hline $18-2$ & 150 & $\begin{array}{l}\text { Late } \\
\text { Pleistocene }\end{array}$ & $\begin{array}{l}\text { Olive carbonate-detrital clayey } \\
\text { siltstone }\end{array}$ & 46.2 & 45.3 & 0.34 & 2.01 & 1.35 & 2189 & 77.0 & 2.79 & 0.5 & 0.03 & 2229 & 129.7 & 129.7 & 15 & 7.1 \\
\hline $19-2$ & 153 & $\begin{array}{l}\text { Late } \\
\text { Pleistocene }\end{array}$ & $\begin{array}{l}\text { Gray carbonate-detrital clayey } \\
\text { siltstone and detrital clayey } \\
\text { silt-rich carbonate chalk }\end{array}$ & 45.2 & 45.8 & 0.35 & 2.00 & 1.36 & 2212 & 75.5 & 2.67 & & & 2186 & 127.1 & 129.0 & 19 & \\
\hline $21-2$ & 167 & $\begin{array}{l}\text { Late } \\
\text { Pliocene }\end{array}$ & $\begin{array}{l}\text { Grayish-olive detrital clayey } \\
\text { silt-carbonate chalk }\end{array}$ & 49.3 & 49.0 & 0.37 & 2.35 & 1.34 & 2368 & 81.6 & 2.50 & 1.0 & 0.06 & 2355 & 137.5 & 136.7 & 16 & 6.6 \\
\hline $24-3$ & 196 & $\begin{array}{l}\text { Late } \\
\text { Pliocene }\end{array}$ & $\begin{array}{l}\text { Greenish-gray alternating beds } \\
\text { of claystone, chalk and siltstone }\end{array}$ & 48.2 & 52.5 & 0.32 & 2.65 & 1.24 & 2553 & 81.9 & 2.43 & 0.9 & 0.05 & 2369 & 136.9 & 147.0 & 14 & 6.3 \\
\hline
\end{tabular}


TABLE 2 - Continued

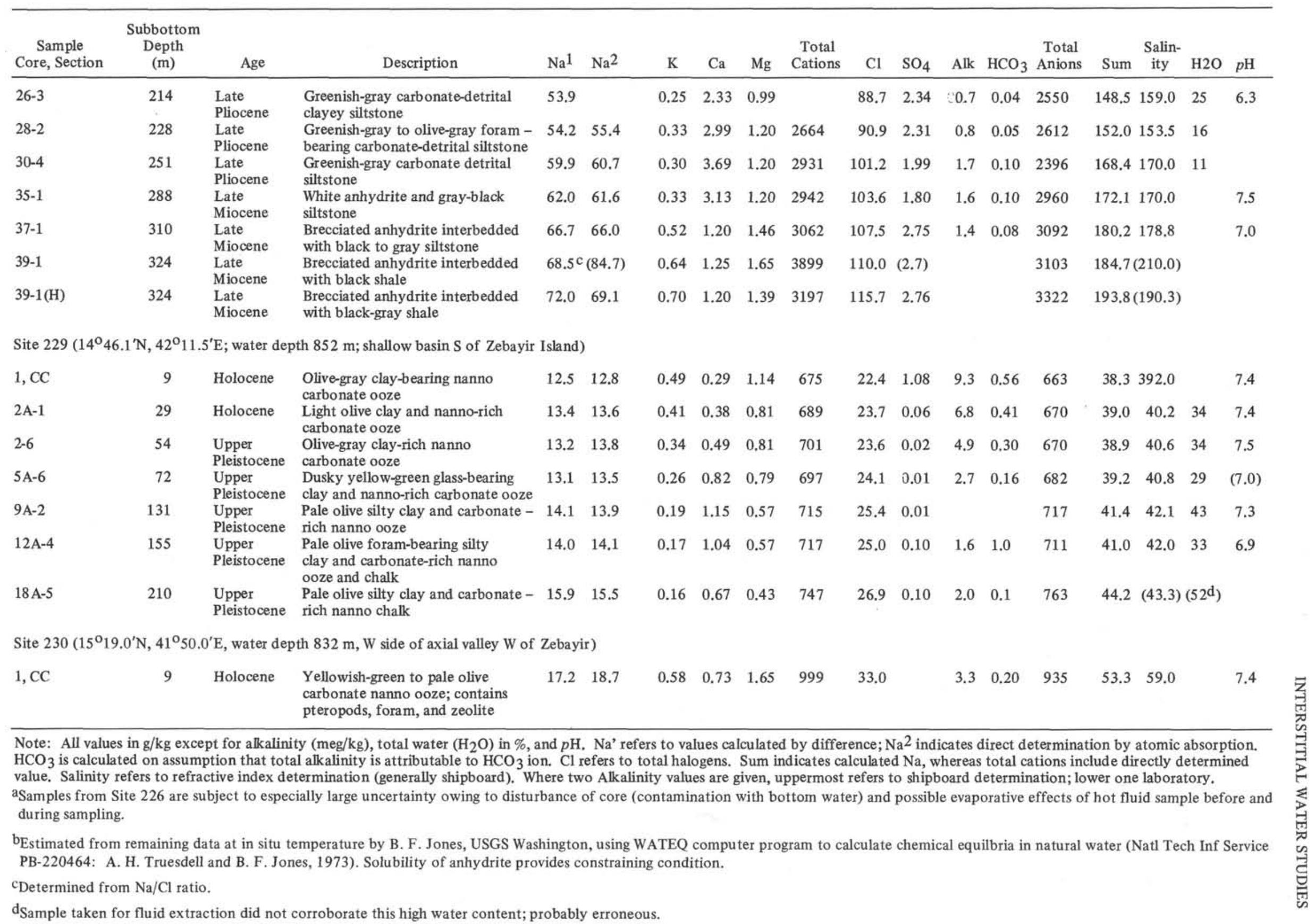


TABLE 3

Minor Constituents (in mg/kg), Leg 23 (Red Sea)

\begin{tabular}{|c|c|c|c|c|c|c|}
\hline $\begin{array}{l}\text { Sample } \\
\text { Core, } \\
\text { Section }\end{array}$ & $\begin{array}{l}\text { Subbottom } \\
\text { Depth } \\
\text { (m) }\end{array}$ & Age & B & $\mathrm{Ba}$ & $\mathrm{Li}$ & $\mathrm{Sr}$ \\
\hline \multicolumn{7}{|c|}{ Site $225\left(21^{\circ} 18.6^{\prime} \mathrm{N}, 38^{\circ} 15^{\prime} \mathrm{E}\right.$; water depth $1228 \mathrm{~m} ; 16 \mathrm{~km} \mathrm{E}$ of Atlantic II Deep) } \\
\hline \multicolumn{3}{|c|}{ Surface ocean water } & 5.5 & $<0.1$ & 0.2 & 8.8 \\
\hline $1-6$ & 8 & Late Pleistocene & 5.5 & $<0.1$ & 0.4 & 9.6 \\
\hline 3-4 & 21 & Late Pleistocene & 5.0 & 0.4 & 0.1 & 10.5 \\
\hline $5-6$ & 34 & Late Pleistocene & 7.0 & 0.2 & 0.3 & 29.0 \\
\hline $8-3$ & 50 & Early Pleistocene & 5.5 & 0.2 & 0.4 & 32.0 \\
\hline $10-2$ & 64 & Late Pliocene & 4.0 & 0.2 & 0.7 & 33.0 \\
\hline $13-6$ & 84 & Late Pliocene & 4.5 & $<0.1$ & 0.2 & 30.0 \\
\hline $16-3$ & 108 & Late Pliocene & 5.5 & 0.8 & 0.9 & 42.0 \\
\hline $18-4$ & 128 & Early Pliocene & 6.5 & 0.4 & 1.0 & 49.0 \\
\hline $21-3$ & 152 & Early Pliocene & 9.0 & 0.4 & 1.4 & 57.0 \\
\hline $23-2$ & 168 & Late Miocene & 5.0 & $<0.16$ & 1.1 & 27.0 \\
\hline 26-1 & 196 & Miocene & 5.5 & $<0.18$ & 1.5 & 11.5 \\
\hline $28-1(\mathrm{H})$ & 212 & Miocene & - & - & - & - \\
\hline \multicolumn{7}{|c|}{ Site $226\left(21^{\circ} 20.5^{\prime} \mathrm{N}, 38^{\circ} 04.9^{\prime} \mathrm{E}\right.$; water depth $2169 \mathrm{~m}$; SW part of Atlantis II Deep) } \\
\hline $1-1$ & 1.5 & Holocene & 10.0 & 1.0 & 4.7 & 46.0 \\
\hline $1-2$ & 1.6 & Holocene & 9.5 & 0.9 & 5.1 & 43.0 \\
\hline $1-4(1 W)$ & 5 & Holocene & 9.0 & 1.1 & 5.3 & 46.0 \\
\hline $1-4(\mathrm{H})$ & 5 & Holocene & 8.0 & 1.4 & 7.5 & 32.0 \\
\hline $1-4(\mathrm{He})$ & 5 & Holocene & 15.0 & 2.6 & 6.8 & 72.0 \\
\hline \multicolumn{7}{|c|}{$\begin{array}{l}\text { Site } 227\left(21^{\circ} 19.9^{\prime} \mathrm{N}, 38^{\circ} 08.0^{\prime} \mathrm{E} \text {; water depth } 1795 \mathrm{~m} \text {; eastern flank }\right. \\
\text { of Atlantis II Deep) }\end{array}$} \\
\hline \multirow{4}{*}{\multicolumn{2}{|c|}{ Surface ocean water }} & & 5.0 & - & 0.2 & 8.8 \\
\hline & & Late Pliocene & 9.3 & $<0.1$ & 0.4 & 19.2 \\
\hline & & Late Pliocene & 5.0 & 0.1 & 0.7 & 21.8 \\
\hline & & Late Pliocene & 4.0 & 0.4 & 0.2 & 18.2 \\
\hline $10-2$ & 75 & Early Pliocene & 5.0 & $<0.1$ & 0.6 & 26.0 \\
\hline $12-2$ & 82 & Early Pliocene & 4.5 & $<0.1$ & 0.9 & 27.0 \\
\hline $14-1$ & 100 & Early Pliocene & 7.0 & 0.2 & (2) & 42.0 \\
\hline $16-1$ & 144 & Early Pliocene & 4.0 & $<0.1$ & 1.0 & 28.0 \\
\hline $18-3$ & 136 & Early Pliocene & 8.0 & 0.1 & 2.1 & 46.0 \\
\hline $20-3$ & 152 & Early Pliocene & 8.5 & 0.1 & 3.2 & 72.0 \\
\hline $23-1$ & 167 & Early Pliocene & 5.5 & 0.1 & 1.7 & 34.0 \\
\hline $25-2$ & 186 & Early Pliocene & $<4.0$ & 0.1 & $<0.1$ & 4.6 \\
\hline $27-1$ & 203 & Early Pliocene & $<4.0$ & 1.3 & 1.7 & 20.0 \\
\hline $30-1$ & 228 & Early Pliocene & - & - & - & - \\
\hline $36-2$ & 282 & Late Miocene & 74.0 & 0.1 & 13.3 & 99.0 \\
\hline $44, \mathrm{CC}$ & 350 & Late Miocene & - & - & - & - \\
\hline
\end{tabular}

\begin{tabular}{|c|c|c|c|c|c|c|}
\hline $\begin{array}{l}\text { Sample } \\
\text { Core, } \\
\text { Section }\end{array}$ & $\begin{array}{l}\text { Subbottom } \\
\text { Depth } \\
\text { (m) }\end{array}$ & Age & B & $\mathrm{Ba}$ & $\mathrm{Li}$ & $\mathrm{Sr}$ \\
\hline \multicolumn{7}{|c|}{$\begin{array}{l}\text { Site } 228\left(19^{\circ} 05.2^{\prime} \mathrm{N}, 39^{\circ} 00.2^{\prime} \mathrm{E} \text {; water depth } 1038 \mathrm{~m} \text {; W side of Red Sea }\right. \\
\text { axial valley })\end{array}$} \\
\hline $1-3$ & 5 & Holocene & 5.0 & $<0.1$ & 0.5 & 20.0 \\
\hline $3, \mathrm{CC}$ & 26 & Late Pleistocene & 5.5 & $<0.1$ & 0.2 & 38.0 \\
\hline $5-3$ & 36 & Late Pleistocene & 6.0 & - & 0.2 & 47.0 \\
\hline $7-6$ & 58 & Late Pleistocene & 6.0 & 0.1 & 0.3 & 72.0 \\
\hline $10-6$ & 76 & Late Pleistocene & 6.0 & 0.2 & 0.4 & 59.0 \\
\hline $11-4$ & 87 & Late Pleistocene & 5.0 & $<0.1$ & 0.4 & 67.0 \\
\hline $13, \mathrm{CC}$ & 105 & Late Pleistocene & 6.5 & $<0.1$ & 0.6 & 84.0 \\
\hline $16-5$ & 129 & Late Pleistocene & 5.5 & - & 0.7 & 78.0 \\
\hline $18-2$ & 150 & Late Pleistocene & $<4.0$ & 0.7 & 0.7 & 62.0 \\
\hline $19-2$ & 153 & Late Pleistocene & 4.0 & 0.4 & 0.6 & 60.0 \\
\hline $21-2$ & 167 & Late Pliocene & 6.0 & 0.5 & 1.0 & 79.0 \\
\hline $24-3$ & 196 & Late Pliocene & 6.0 & $<0.1$ & 1.3 & 87.0 \\
\hline $26-3$ & 214 & Late Pliocene & 4,5 & 0.2 & 0.8 & 56.0 \\
\hline $28-2$ & 228 & Late Pliocene & $<4.0$ & 0.2 & 0.7 & 62.0 \\
\hline $30-4$ & 251 & Late Pliocene & 4.0 & 0.3 & 1.4 & 84.0 \\
\hline $33-1$ & 268 & Early Pliocene & 5.0 & 1.3 & 1.3 & 82.0 \\
\hline $35-1$ & 288 & Late Miocene & 6.0 & 0.7 & 1.8 & 104.0 \\
\hline $37-1$ & 310 & Late Miocene & 4.0 & 0.4 & 2.7 & 50.0 \\
\hline $39-1$ & 324 & Late Miocene & - & - & - & - \\
\hline 39-1 (H) & 324 & Late Miocene & $\leq 4.0$ & 0.2 & 2.0 & 32.0 \\
\hline
\end{tabular}

Site $229\left(14^{\circ} 46.1^{\prime} \mathrm{N}, 42^{\circ} 11.5^{\prime} \mathrm{E}\right.$; water depth $852 \mathrm{~m}$; shallow basin $\mathrm{S}$ of

Zebayir Island)

$\begin{array}{lrlrrrr}1, \mathrm{CC} & 1 & \text { Holocene } & 6.0 & <0.1 & 0.2 & 10.2 \\ 2 \mathrm{~A}-1 & 29 & \text { Holocene } & 7.0 & 0.5 & 0.2 & 23.0 \\ 2-6 & 54 & \text { Upper Pleistocene } & 7.5 & 0.4 & 0.2 & 40.0 \\ 5 \mathrm{~A}-6 & 72 & \text { Upper Pleistocene } & 4.5 & 0.6 & 0.1 & 69.0 \\ \text { 3-5 } & 99 & \text { Upper Pleistocene } & 6.5 & 0.1 & 0.4 & 85.0 \\ 9 \mathrm{~A}-2 & 131 & \text { Upper Pleistocene } & 6.0 & 0.5 & 0.2 & 137.0 \\ 12 \mathrm{~A}-4 & 155 & \text { Upper Pleistocene } & 5.5 & 0.3 & 0.2 & 137.0 \\ 15 \mathrm{~A}-1 & 177 & \text { Upper Pleistocene } & 8.0 & 1.5 & 0.4 & 142.0 \\ 18 \mathrm{~A}-5 & 210 & \text { Upper Pleistocene } & 8.0 & 1.0 & 0.4 & 109.0\end{array}$

Site $230\left(15^{\circ} 19.0^{\prime} \mathrm{N}, 41^{\circ} 50.0^{\prime} \mathrm{E}\right.$; water depth $832 \mathrm{~m}$; W side of axial valley W of Zebayir Island)

$\begin{array}{lllllll}1, \mathrm{CC} & 9 & \text { Holocene } & 8.5 & <0.1 & 0.2 & 44.0\end{array}$




\section{ACKNOWLEDGMENTS}

We wish to especially thank the shipboard technicians of Leg 23 for efficiently and conscientiously assisting in collecting and documenting the large fund of data on which this report is based. These technicians, led by R. J. Iuliucci, were K. Van Allyn, B. W. Hamlin, M. L. Henry, G. L. Jones, D. F. Marsie, L. G. Russill, L. G. Schneider, D. Siems and P. G. Thompson. We thank Captain J. Clarke and his crew in particular for their efforts in manually keeping Glomar Challenger on station when the computer could not cope and T. Bangs for his advice and guidance on how to reach our scientific objectives. The geochemical program in the Red Sea was especially successful due to the preparations and enthusiasm of F. T. Manheim. Many people assisted us in choosing sites by freely allowing access to unpublished data and by discussions. We are indebted, therefore, to $\mathrm{H}$. Backer; E. T. Bunce; J. I. Ewing; M. Ewing; R. Harbison; J. I. Heirtzler; J. M. Hunt; A. S. Laughton; D. H. Matthews; G. Pyre, and his colleagues of the Gulf Oil Company, London; F. Sayles; and M. Talwani. The assistance of the Deep Sea Drilling Project staff in all the phases of Leg 23 is gratefully acknowledged. 